\section{KEPEMIMPINAN PEMERINTAHAN}

\section{KOTA TANGERANG SELATAN}

Kepemimpinan adalah topik yang masih kekinian, relevan dan tetap menarik untuk dibahas. Sejak dari zaman kuno sampai abad 21 ini Kepemimpinan terus menerus berkembang mengikuti perubahan dan perkembangan zaman. Dari sebuah Kepemimpinan diyakini bisa memilliki efek perubahan yang luar biasa besar dan mampumengubah suatu peradaban.

Buku ini membahas tentang Kepemimpinan Pemerintahan Walikota Tangerang Selatan periode Tahun 2011 - 2016, Kepemimpinannya menarik untuk diamati dan dicermati karena telah menjadikan Kota Tangerang Selatan di usia yang masih belia, tumbuh dan berkembang bak seorang bayi ajaib yang telah mencetak banyak prestasi dan penghargaan baik di lingkup provinsi, nasional maupun internasional, Semakin menarik karena adanya dinamika kontroversi di kepemimpinannya yang menyeruak ke publik.

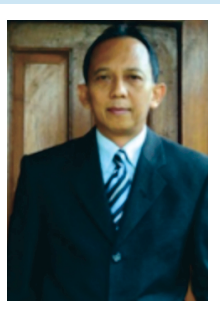

Ednawan Prihana, Mengambil pendidikan S1 di Ilmu Komunikasi FISIPOL Universitas Gadjah Mada Jogjakarta, S2 di Pascasarjana Ilmu Pemerintahan UNPRI dan saat ini sedang menyelesaikan S3 di Program Pascasarjana Doktor Ilmu Pemerintahan Institut Pemerintahan Dalam Negeri (IPDN).

Selain aktif mengajar sebagai dosen di Perguruan Tinggi, la aktif pula di dunia pendidikan Anak dan Remaja. Saat ini ia menjabat sebagai Direktur LPPM UNPRI, Ketua Redaksi Jurnal LENSA, CEO \& Founder Brainy Indonesia dan Chief Marketing Officer (CMO) REI Edu Consultant. Tak lupa ia aktif di berbagai kepengurusan organisasi maupun kegiatan sosial kemasyarakatan lainnya.
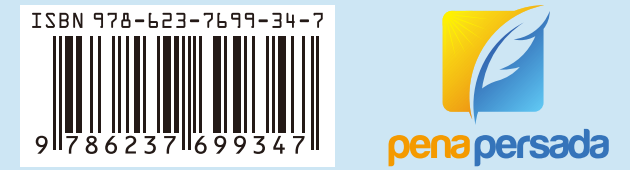

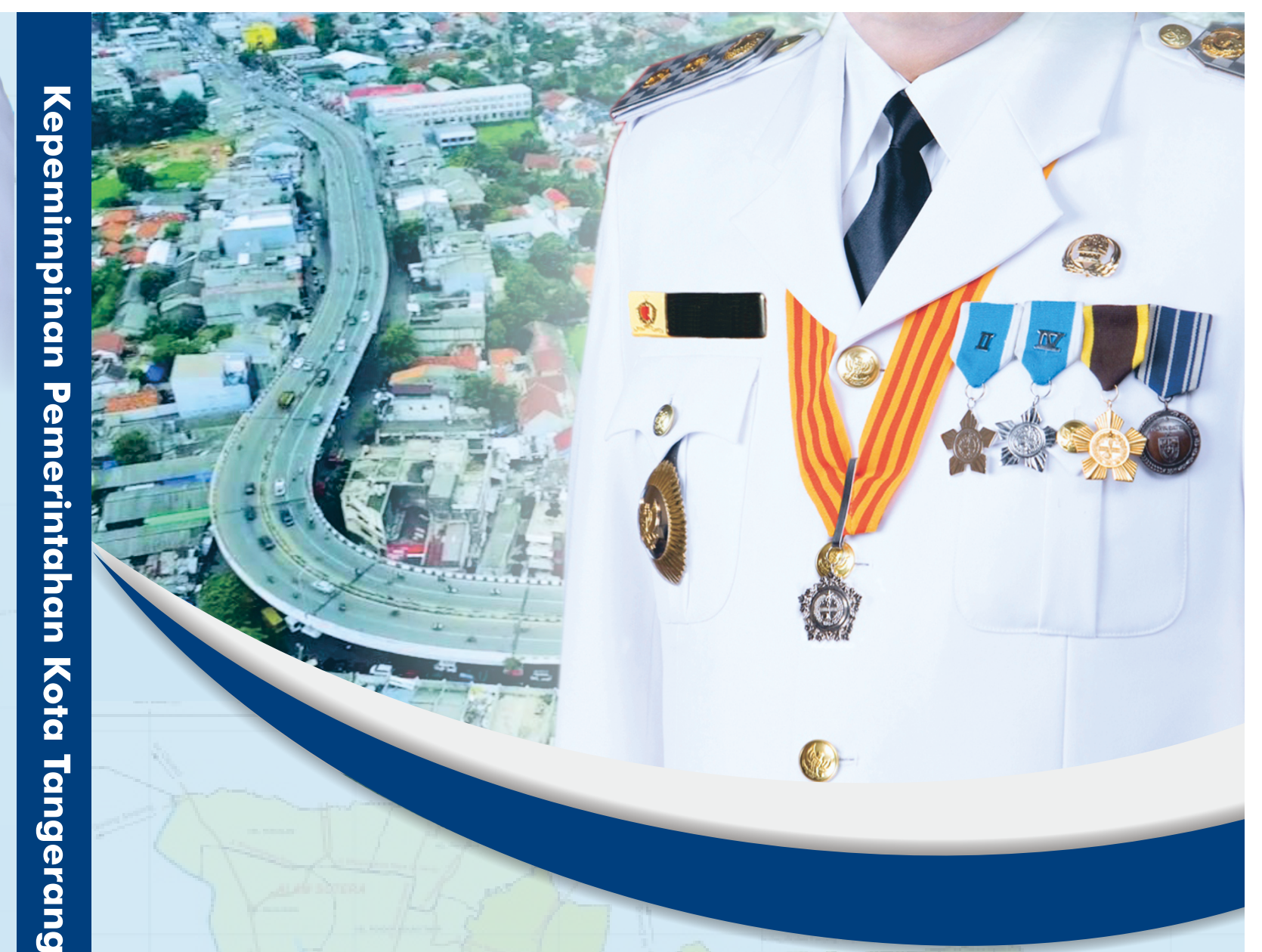

Dr.(c) Ednawan Prihana, M.Si

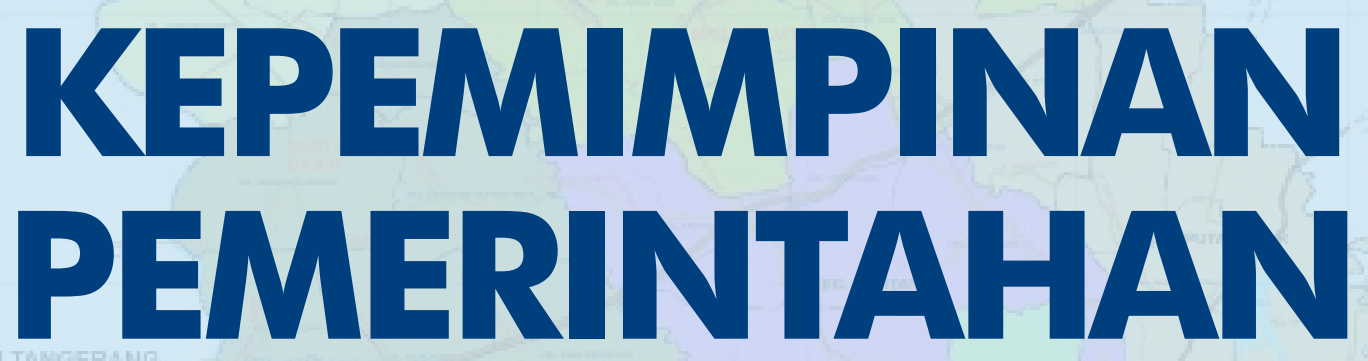

KOTA TANGERANG SELATAN 


\section{KEPEMIMPINAN PEMERINTAHAN KOTA TANGERANG SELATAN}

Dr.(c) Ednawan Prihana, M.Si

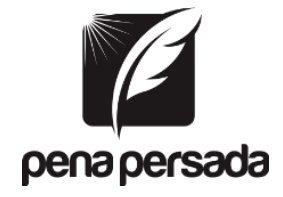

PENERBIT CV. PENA PERSADA 


\title{
KEPEMIMPINAN PEMERINTAHAN \\ KOTA TANGERANG SELATAN
}

\author{
Penulis : \\ Dr.(c) Ednawan Prihana, M.Si \\ ISBN : 978-623-7699-34-7
}

Editor :

Tri Hidayati

Desain Sampul :

Retnani Nur Briliant

Penata Letak :

Fajar T. Septiono

\section{Penerbit CV. Pena Persada}

\section{Redaksi :}

Jl. Gerilya No. 292 Purwokerto Selatan, Kab. Banyumas

Jawa Tengah

Email : penerbitpenapersada@gmail.com

Website : penapersada.com

Phone : (0281) 7771388

\section{Anggota IKAPI}

All right reserved

Cetakan pertama : 2020

Hak Cipta dilindungi oleh undang-undang.

Dilarang memperbanyak karya tulis ini dalam bentuk dan cara apapun tanpa izin penerbit 
"No matter how effective your strategy, your vision, or your communication, You will fail to achieve the desired results for your organizations if you cannot inspire trust.."

(Bill Goerge)

"Before you are a leader, success is all about growing yourself. When you become a leader, success is all about growing others."

(Jack Welch)

"Leaders become great, not because of their power, but because of their ability to empower others"

(John Maxwell)

"If your actions inspire others to dream more, learn more, do more and become more, you are a leader"

(John Quincy Adams)

"Be with a leader when he is RIGHT, stay with him when he is still RIGHT, but leave him when he is WRONG"

(Abraham Lincoln)

"A good leader leads the people from above them. A great leader leads the people from within them"

(M.D.Arnold)

"If you build an army of 100 lions and their leader is a dog, in any fight the lions will die like a dog. But if you build an army of 100 dogs an their leader is a lion, all dogs will fight like a lion"

(Napoleon Bonaparte)

"“When women participate in the economy, everyone benefits. When women participate in peace-making and peace-keeping, we are all safer and more secure. And when women participate in politics of their nations they can make a difference."

(Hillary Clinton) 


\section{KATA PENGANTAR}

Segala kemuliaan dan rasa syukur kehadirat Allah SWT atas rahmat dan hidayah-Nya, shalawat dan salam kepada Nabi Muhammad, keluarga dan para sahabat beliau. Alhamdulilah tesis ini bisa saya selesaikan dalam segala keterbatasan, baik waktu dan semua keterbatasan yang ada. Buku ini adalah hasil dari tesis penulis dengan judul: "Analisis Kepemimpinan Walikota Tangerang Selatan Periode Tahun 2011-2016 Dalam Penyelenggaraan Pemerintahan Kota Tangerang Selatan". Penelitian tesis dalam rangka menyelesaikan studi Program Pendidikan S-2 Magister Ilmu Pemerintahan di Universitas Pramita Indonesia. Publikasi hasil tesis tersebut dalam bentuk buku diharapkan bisa memberikan informasi dan wawasan atas diskursus kepemimpinan dan pemerintahan di Indonesia.

Buku ini membahas tentang Kepemimpinan karena bagi saya Kepemimpinan adalah topik yang masih kekinian, relevan dan tetap menarik untuk dibahas. "Leadership is the process of influencing people by providing purpose, direction, and motivation while operating to accomplish the mission and improving the organization." Selain itu, sejak dari zaman kuno sampai abad 21 ini Kepemimpinan terus menerus berkembang mengikuti perubahan dan perkembangan zaman. Dari sebuah Kepemimpinan diyakini bisa memilliki efek perubahan yang luar biasa besar dan mampu mengubah suatu peradaban.

Kepemimpinan Walikota Tangerang Selatan periode Tahun 2011 - 2016 bagi saya sangat menarik untuk diamati dan dicermati karena telah menjadikan Kota Tangerang Selatan di usia yang masih belia, tumbuh dan berkembang bak seorang bayi ajaib yang telah mencetak banyak prestasi dan penghargaan baik di lingkup provinsi, nasional maupun internasional, Ditambah adanya dinamika kontroversi kepemimpinan yang timbul dan menyeruak di publik sehingga menjadikan lebih menarik untuk dijadikan bahan penelitian serta dapat lebih memperkaya wawasan keilmuan saya dalam bidang ilmu pemerintahan. 
Akhirnya, hanya ada harapan kiranya buku ini dapat bermanfaat bagi para pembaca dalam mengembangkan dan memperkaya khasanah kepemimpinan dalam penyelenggaraan pemerintahan. Semoga buku ini dapat menjadi sedikit sumbangan pemikiran yang diharapkan dapat bermanfaat bagi pengembangan Ilmu Pemerintahan pada umumnya dan khususnya bagi Pemerintahan Kota Tangerang Selatan dalam penyelenggaraan pemerintahan. Saya sangat menyadari bahwa kajian pada buku ini masih banyak kekurangannya. Hal ini karena keterbatasannya kemampuan sehingga saya sangat mengharapkan saran dan kritik yang konstruktif demi kesempurnaan buku ini. Akhir kata semoga bermanfaat bagi pembaca, khususnya bagi saya pribadi sebagai bekal dalam menimba Ilmu Pemerintahan. Aamiin.

Tangerang, 20 Januari 2020

Dr.(c) Ednawan Prihana, M.Si 


\section{DAFTAR ISI}

KATA PENGANTAR ............................................................... ii

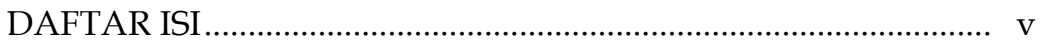

BAB I

PENDAHULUAN …….......................................................... 1

A. Definisi Kepemimpinan....................................................... 1

B. Kepemimpinan pada Kota Tangerang Selatan dan

Tantangan yang dihadapi ......................................................... 2

BAB II

KEPEMIMPINAN DAN PEMERINTAHAN ............................. 11

A. Konsep Kepemimpinan ........................................................ 11

1. Tugas Kepemimpinan ...................................................... 14

2. Peran Kepemimpinan................................................. 15

B. Teori Kepemimpinan ………………................................... 16

C. Gaya Kepemimpinan ........................................................... 23

1. Gaya Kepemimpinan Keating .......................................... 23

2. Gaya Kepemimpinan Kontinum..................................... 26

3. Gaya Kepemimpinan Jalur Tujuan (Path Goal) .............. 27

4. Gaya Kepemimpinan Situasional Hersey Blanchart...... 30

5. Gaya Kepemimpinan Lippit \& White ............................. 33

D. Membangun Kepemimpinan Efektif ..................................... 38

E. Konsep Pemerintahan ........................................................ 44

F. Pemerintahan Daerah ......................................................... 46

G. Otonomi Daerah ................................................................. 47

H. Desentralisasi ........................................................................... 48

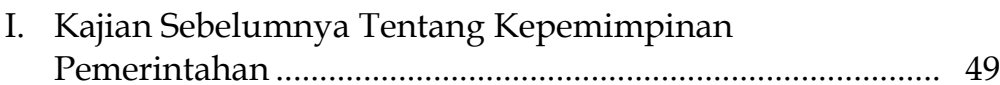

BAB III

KEPEMIMPINAN PEMERINTAHAN TANGERANG

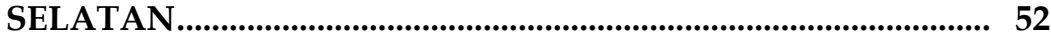

A. Kondisi Geografis Daerah Tangerang Selatan..................... 52

B. Kondisi Demografis .............................................................. 55

C. Kondisi Ekonomi .................................................................. 57

D. Kondisi Pemerintahan Daerah Kota Tangerang Selatan.... 64

E. Sejarah Pemerintahan Kota Tangerang Selatan.................... 74

F. Kepemimpinan Walikota Tangerang Selatan

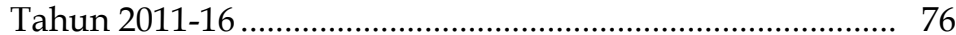

1. Karakteristik Kepemimpinan yang Menonjol................. 76

2. Tipe Kepemimpinan .......................................................... 90

3. Kontroversi Kepemimpinan............................................... 103 
G. Penyelenggaraan Pemerintahanan Kota Tangerang Selatan Tahun 2011 - 2016 .................................................. 108

1. Urusan Wajib Yang Dilaksanakan ................................. 117

2. Permasalahan di Kota Tangerang Selatan .................... 129

BAB IV

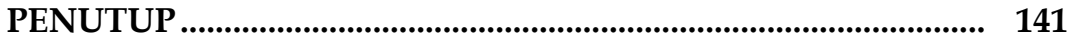

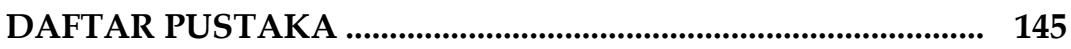





\title{
BAB I \\ PENDAHULUAN
}

\section{A. Definisi Kepemimpinan}

Keberadaan bupati atau walikota sebagai seorang pemimpin daerah di era otonomi daerah sangatlah penting. Menurut Kaloh ( 2009 ) :

\begin{abstract}
"Sebagai seorang pemimpin kepala daerah adalah orang yang bergerak lebih awal atau memelopori, mengerahkan pikiran dan pendapat anggota organisasi, membimbing, menuntun, menggerakkan orang lain melalui pengaruhnya, menetapkan tujuan organisasi dan harus dapat memengaruhi sekaligus melakukan pengawasan atas pikiran, perasaan dan tingkah laku aparatur pemerintahan yang ia pimpin."
\end{abstract}

Kepemimpinan publik di daerah memiliki peran yang sangat penting dalam menentukan kinerja organisasi publik dan kinerja pejabat dibawahnya. Dalam keberhasilan dan kemunduran organisasi sangat ditentukan oleh faktor kepemimpinan dan ketercapainya visi dan misi organisasi tersebut. Begitu pula dengan kemajuan suatu daerah sangat ditentukan dari keberhasilan terobosan dan inovasi yang dilakukan oleh pemimpin publik dalam menciptakan visi dan misi yang realistis dan terukur. Dalam struktur pemerintahan daerah, pemimpin daerah berperan dalam menciptakan visi yang strategis, dan mempunyai pandangan jauh kedepan untuk memajukan daerah serta menyejahterakan rakyatnya.

Kepemimpinan merupakan salah satu isu dalam manajemen yang masih cukup menarik untuk diperbincangkan hingga dewasa ini. Media massa, baik elektronik maupun cetak, seringkali menampilkan opini dan pembicaraan yang membahas seputar kepemimpinan (Locke, E.A, 1997). Peran kepemimpinan yang sangat strategis dan penting bagi pencapaian misi, visi dan tujuan suatu organisasi, merupakan 
salah satu motif yang mendorong manusia untuk selalu menyelidiki seluk-beluk yang terkait dengan kepemimpinan. Kualitas dari pemimpin seringkali dianggap sebagai faktor terpenting dalam keberhasilan atau kegagalan organisasi (Bass, 1990, dalam Menon, 2002).

Kepemimpinan terkadang dipahami sebagai kekuatan untuk menggerakkan dan memengaruhi orang lain, Rivai (Kepemimpinan dan Perilaku Organisasi, 2014 : 2) mengatakan bahwa kepemimpinan sebagai sebuah alat, sarana atau proses untuk membujuk orang agar bersedia melakukan sesuatu secara sukarela/suka cita. Ada beberapa faktor yang dapat menggerakkan orang yaitu karena ancaman, penghargaan, otoritas, dan bujukan.

\section{B. Kepemimpinan pada Kota Tangerang Selatan dan Tantangan} yang dihadapi

Kota Tangerang Selatan pada tahun 2014 mendapat predikat terbaik pertama sebagai daerah otonomi baru. Penilaian berdasarkan beberapa indikator seperti struktur Anggaran Pendapatan dan Belanja daerah (APBD) yang terus meningkat dari tahun ke tahun, tahun 2011 sebesar Rp. 1.306 triliun, tahun 2013 sebesar Rp. 1.830 triliun dan tahun 2015 mencapai Rp. 3.310 triliun. Pendapatan Asli Daerah (PAD) juga mengalami lonjakan signifikan dari tahun ke tahun. Tahun 2011 sebesar Rp.420,663 miliar, di tahun 2013 melonjak menjadi Rp. 728,965 miliar dan tahun 2015 sebesar Rp. 1.227 triliun.

Tangerang Selatan merupakan salah satu kota yang telah memiliki Peraturan daerah (Perda) tentang Rencana Tata Ruang Wilayah (RTRW) sebagai acuan, pedoman, aturan dan ketentuan dalam menyusun rencana dan pelaksanaan pembangunan di kota Tangerang Selatan agar pembangunan bisa terarah, terpadu dan tepat sasaran.

Pencapaian pembangunan di bidang infrastruktur jalan raya kota Tangerang Selatan meningkat, pada tahun 2011 panjang jalan sekitar $169 \mathrm{~km}$ dan sebagian besar dalam kondisi rusak, namun tahun 2015 telah mencapai $360 \mathrm{~km}$ dan dalam 
kondisi baik. Jembatan juga telah banyak diperbaiki, situ dan normalisasi kali.

Di bidang pelayanan pendidikan, tahun 2011 masih banyak terdapat siswa SD dan SMP yang masuk siang, saat ini semua siswa sudah bersekolah pagi hari dan gratis biaya SPP. Rata-rata lama sekolah meningkat, di tahun 2011 di angka 10,17 tahun dan tahun 2015 menjadi 11,56 tahun dan merupakan capaian tertinggi di provinsi Banten.

Di bidang sosial dan ketenagakerjaan, pada tahun 2011 tingkat pengangguran di Tangerang Selatan mencapai 11,98 \% namun saat ini menurun menjadi 6,9\%. Tingkat kemiskinan semula $1.69 \%$, tahun 2015 menjadi 1, $62 \%$.

Dalam bidang pelayanan publik adanya pelayanan perizinan online, yaitu sistem informasi manajemen perizinan (Simponie), Simponie menjadi sistem layanan perizinan online pertama di Indonesia dan meraih penghargaan ISO 9001. Menerapkan pula teknologi dalam kependudukan, rumah sakit, elektronik musrenbang serta adanya sistem perencanaan penganggaran dan pelaporan secara online (simral), yang telah mendapat penghargaan ISO 27001. Adanya pula Sistem Informasi Manajemen Puskesman (Simpus) dimana sistem ini mengintegrasikan puskesmas, Pasien atau pihak yang diizinkan dapat mengetahui rekam medis dimana pun dan kapan pun.

Di bidang pemerintahan adanya aplikasi untuk suratmenyurat secara digital melalui Sistem Informasi Surat Masuk dan Keluar (Sisumaker) yang merupakan implementasi egoverment yang lebih efektif, efisien dan akan memudahkan komunikasi antar SKPD.

Di bidang pelayanan kesehatan, bagi yang memiliki e KTP (Kantu Tanda Penduduk) Tangerang Selatan gratis pelayanan kesehatan di RSUD Tangerang Selatan. Angka Harapan Hidup penduduk Tangerang Selatan juga meningkat, yang semula 68,57 di tahun 2011 sekarang ini menjadi 72,11 tahun. Berikut ini adalah tabel lengkap capaian 8 Indikator 
Makro Daerah Kota Tangerang Selatan periode Tahun 2011 2014:

Tabel 1.1

Capaian Indikator Makro Daerah Kota Tangerang Selatan

\begin{tabular}{|c|c|c|c|c|c|}
\hline No. & Uraian & Th 2011 & Th 2012 & Th 2013 & Th 2014 \\
\hline 1 & $\begin{array}{c}\text { Indeks } \\
\text { Pembangunan } \\
\text { Manusia (IPM) }\end{array}$ & 76.99 & 77.68 & 78.65 & 79.17 \\
\hline 2 & $\begin{array}{c}\text { Angka Melek } \\
\text { Huruf (AMH/\%) }\end{array}$ & 98.19 & 98.51 & 98.62 & 98.62 \\
\hline 3 & $\begin{array}{c}\text { Rara-rata } \\
\text { Lamanya Sekolah } \\
\text { (RLS/tahun) }\end{array}$ & 10.87 & 10.98 & 10.99 & 11.56 \\
\hline 4 & $\begin{array}{l}\text { Angka Harapan } \\
\text { Hidup } \\
\text { (AHH/tahun) }\end{array}$ & 72.07 & 72.09 & 72.10 & 72.11 \\
\hline 5 & $\begin{array}{l}\text { Laju Pertumbuhan } \\
\text { Ekonomi (LPE) }\end{array}$ & $8.81 \%$ & $8.24 \%$ & $8.48 \%$ & $8.99 \%$ \\
\hline 6 & $\begin{array}{c}\text { PDRB/ } \\
\text { Income Per kapita }\end{array}$ & $25.73 \mathrm{jt}$ & $27.81 \mathrm{jt}$ & $30.91 \mathrm{jt}$ & $34.31 \mathrm{jt}$ \\
\hline 7 & $\begin{array}{c}\text { Tingkat } \\
\text { Kemiskinan }\end{array}$ & $1.5 \%$ & $1.33 \%$ & $1.75 \%$ & $1.62 \%$ \\
\hline 8 & $\begin{array}{c}\text { Tingkat } \\
\text { Pengangguran }\end{array}$ & $11.98 \%$ & $8.07 \%$ & $4.56 \%$ & $6.92 \%$ \\
\hline
\end{tabular}

Sumber : LKPJ Akhir Masa Jabatan Walikota Tangerang Selatan Tahun 2011-16

Capaian Indikator Makro Daerah selama kurun waktu 2011-2014 telah mencerminkan tingkat pertumbuhan sosial ekonomi yang baik secara keseluruhan dan berada diatas ratarata di Provinsi Banten, Indeks Pembangunan Manusia (IPM) tertinggi di Provinsi Banten, penduduk miskin 1,62 \% di Tahun 2014 terendah diprovinsi Banten, Angka Harapan Hidup 
$(\mathrm{AHH}) \quad 72,11$ tahun mencerminkan derajat kesehatan masyarakat yang semakin baik.

Dengan berbagai keberhasilan-keberhasilan yang telah dicapai tersebut, pemerintah Kota Tangerang Selatan telah mendapatkan berbagai penghargaan baik di lingkup internasional, nasional maupun provinsi. Berbagai keberhasilan dan penghargaan yang telah diraih Kota Tangerang Selatan bukanlah seperti durian runtuh atau jatuh dari langit, namun tentu saja tak lepas dari kepemimpinan Walikota Tangerang Selatan periode tahun 2011 - 2016.

Namun, dalam kepemimpinan Walikota Tangerang Selatan tersebut tak lepas pula dari berbagai permasalahan yang timbul, masih banyak pekerjaan rumah yang harus dibenahi dan memerlukan usaha lebih agar permasalahanpermasalahan yang ada bisa terselesaikan, Salah satunya adalah adanya beberapa kasus bangunan komersial maupun perumahan yang tidak memiliki IMB (Izin Mendirikan Bangunan) namun proses pembangunannya telah terjadi. Hal ini seperti pada pemberitaan di beberapa media, salah satunya di metronews.com pada 1 April 2016 yang memberitakan bahwa ada sekitar 40 bangunan showroom mobil di kawasan Bintaro, Tangerang Selatan tak memiliki IMB namun pembangunan tetap berlangsung. Bahkan, sentra jual-beli mobil tersebut yang dimiliki olh PT Jaya Grup rencananya dibuka pada tanggal 2 April 2016 namun rupanya sebelum telanjur dibuka telah dilakukan penyegelan pada tanggal 28 Maret 2016 oleh Satuan Polisi Pamong Praja (Satpol PP) Kota Tangerang Selatan, BP2T (Badan Pelayanan Perizinan Terpadu) beserta Komisi IV DPRD Tangerang Selatan.

Permasalahan lain adalah adanya beberapa pengembang yang tidak memenuhi aturan dalam hal penyediaan sarana fasilitas umum dan fasilitas sosial yang sebenarnya merupakan kewajiban pengembang dalam pembangunan perumahan yang tertuang di dalam peraturan daerah. Pengembang seperti itu semestinya ditindak tegas agar pembangunan di Kota Tangerang Selatan dapat berjalan secara baik, sesuai aturan 
dan bisa optimal hasilnya. Beberapa pengembang berusaha mangkir untuk memenuhi kewajiban memberikan fasum dan fasos seperti tertuang dalam persyaratan IMB.

Masalah sampah juga merupakan permasalahan menahun di Kota Tangerang Selatan, Pemerintah Kota belum mampu menangani masalah sampah secara maksimal selama lima tahun terakhir ini, masalah sampah mestinya menjadi skala prioritas, bahkan ancaman krisis sampah masih menghantui kota Tangerang Selatan menyusul penuhnya Tempat Pengolahan Akhir Sampah Cipecang satu satunya milik pemerintah kota itu. Banyak kendala yang merintangi program penanganan sampah di kota Tangerang Selatan, dari kesadaran masyarakat yang tidak paham cara mengelola sampah yang baik, sulitnya mendapatkan teknologi pengolahan sampah yang canggih dan tepat hingga terbatasnya lahan TPA Cipecang. Produksi sampah di Tangerang Selatan mencapai 800 ton setiap harinya, sampah tersebut dihasilkan dari 500.000 kepala keluarga, pasar tradisional dan kawasan pertokoan. Dari sekian banyak sampah tersebut, hanya 30 persen yang terangkut ke TPA Cipecang, 20 persen tereduksi melalui bank sampah, tempat pengolahan sampah $3 \mathrm{R}$ yang kini beroperasi sebanyak 41 titik, sisanya belum tertangani.

Meski hanya menampung 30 persen sampah Tangerang Selatan setiap harinya, TPA Cipecang saat ini sudah penuh. Tingginya tumpukan sampah bisa mencapai 12 meter dan telah memenuhi area sanitary landfill seluas 1 hektar. Upaya pemerintah Tangerang Selatan untuk memperluas TPA meleset dari target karena terkendala lahan. Target pemerintah daerah membebaskan lahan seluas 10 hektar sejak tahun 2012 tidak membuahkan hasil, karena pemilik lahan menolak tanahnya dibeli. Padahal pemerintah Tangerang Selatan sudah menganggarkan Rp 35 miliar di APBD. Hasilnya, sejak tahun 2012 hingga 2015, hanya 5,5 hektar yang berhasil dibebaskan.

Permasalahan lain yang muncul adalah dalam hal penyerapan anggaran belanja daerah, kondisi objektif masih besarnya sisa anggaran belanja daerah. Data dari Laporan 
Keuangan Pemerintah Kota Tangerang Selatan TA 2014 dan 2015 hasil audit BPK RI, pada Tahun 2014 anggaran jumlah belanja daerah Rp. 2.698 triliun namun realisasi belanja hanya mencapai Rp. 2.086 triliun atau sebesar 77,31 \%. Sedangkan anggaran jumlah belanja daerah Tahun 2015 sejumlah Rp. 3.310 triliun sedangkan realisasi penyerapan anggaran Rp. 2.611 triliun atau sebesar 78,59 \%. Hal ini akan berdampak dalam pencapaian RPJMD (Rencana Pembangunan Jangka Menengah Daerah) di Kota Tangerang Selatan.

Potensi pendapatan dari pajak dan retribusi daerah di Kota Tangerang Selatan terus mengalami perkembangan yang signifikan, berdasarkan data terakhir dari Laporan Keuangan Kota Tangerang Selatan TA 2015 unAudit (DPPKAD,2015) hasil pajak daerah dan retribusi daerah mencapai Rp. 1, 159 triliun, namun permasalahannya masih banyak potensi pajak yang belum berhasil dipungut. Sebagai kota perdagangan dan jasa, Kota Tangerang Selatan juga mengalami peningkatan investasi, khususnya di sektor tersier (perdagangan, hotel dan restoran, sektor pengangkutan dan komunikasi, sektor keuangan, jasa persewaan dan sektor jasa-jasa lainnya), hal itu berarti potensi dari pendapatan pajak dan retribusi daerah sangat besar, semestinya jika hal ini digarap lebih serius lagi akan meningkatkan pendapatan daerah secara signifikan.

Hal lain yang menjadi permasalahan di Kota Tangerang Selatan adalah proses pengadaan barang dan jasa masih belum sepenuhnya dapat dilaksanakan tepat waktu sesuai jadwal rencana penyelesaian pekerjaan sehingga berdampak pada mundurnya waktu pelaksanaan program, Contohnya adalah pada tahun 2013 terdapat 211 paket pekerjaan yang tidak selesai sehingga berakibat terjadinya sisa anggaran sebesar Rp. 75.65 miliar. Tahun 2014 terdapat sisa anggaran sebesar Rp. 211.4 miliar diantaranya disebabkan adanya paket yang batal lelang dikarenakan bangunan fisik yang dikerjakan sebelumnya (tahap 1) masih belum bisa selesai dikerjakan.

Keterlambatan pelelangan proyek juga masih terjadi di tahun 2016 ini walaupun diawal tahun 2016, Walikota 
Tangerang Selatan mengingatkan para Kepala Satuan Kerja Perangkat daerah (SKPD) untuk mempersiapkan lelang proyek agar tidak terjadi keterlambatan seperti tahun 2015 (Tangerang Express, 19 April 2016). Data yang dikeluarkan dari Lelang Pengadaan Secara Elektronik (LPSE) Kota Tangerang Selatan, di bulan April 2016 ini dari lebih 1000 paket pelelangan proyek, baru dirilis 64 paket, dan dari 64 paket hanya ada 10 paket yang nilai kontraknya diatas satu miliar. Dari permasalahan diatas jika proses lelangnya juga mengalami keterlambatan dan pada bulan April 2016 masih sedikit proyek yang akan dilelangkan maka hal ini akan berdampak luas dalam proses pembangunan dan penyelesaian pembangunan yang tidak tepat waktu serta mengakibatkan penyerapan anggaran tahun 2016 , seperti yang telah terjadi di tahun-tahun sebelumnya akan menjadi tidak optimal.

Permasalahan lain adalah adanya opini yang muncul dan menyeruak ke ranah publik, yaitu terkait dugaan politik dinasti kekuasaan di Banten. Beberapa jabatan penting dan strategis di wilayah Banten berasal dari salah satu kerabat atau keluarga berpengaruh di Banten. Dan kebetulan Walikota Tangerang Selatan merupakan satu dari kerabat keluarga berpengaruh tersebut. Juga opini publik yang muncul di sebagian masyarakat pada tahun 2015 lalu terkait dugaan kasus korupsi alat kesehatan di lingkungan pemerintahan Kota Tangerang Selatan yang telah ditangani oleh Komisi Pemberantasan Korupsi (KPK). Kasus ini telah menarik perhatian khalayak publik.

Berdasarkan hal yang telah dipaparkan diatas, ditengahtengah gegap gempita perkembangan dan keberhasilan yang telah diraih Kota Tangerang Selatan, Namun masih timbul adanya permasalahan dan kontroversi kepemimpinannya.

Bagi penulis hal ini menjadi sesuatu hal yang menarik untuk ditelaah, dikaji dan dteliti lebih mendalam. Sebuah kepemimpinan yang fenomenal, banyak keberhasilan yang telah dicapai meskipun masih ada pula permasalahan yang timbul dengan adanya kontroversi kepemimpinannya. Oleh 
karena itu penulis mencoba menyusun buku ini untuk melihat secara jelas bagaimana konsep kepemimpinan dalam pemerintahan Kota Tangerang selatan. Buku ini merupakan hasil dari tesis penulis yang dengan judul "Analisis Kepemimpinan Walikota Tangerang Selatan Periode Tahun 2011-16 dalam Penyelenggaraan Pemerintahan Kota Tangerang Selatan." Dengan penyusunan buku ini, diharapkan hasil tesis penulis bisa bermanfaat bagi masyarkat dan dapat ditelaah oleh masyarakat dan pemangku kebijakan agar tercipta kepemimpinan yang baik.

Selama kurun waktu tahun 2011 - 2016 banyak hal yang telah dicapai di kepemimpinan Walikota Tangerang Selatan dalam penyelenggaraan pemerintahan daerah di Kota Tangerang Selatan. Dalam proses pelaksanaannya masih tersisa permasalahan yang timbul. peneliti menemukan beberapa masalah, antara lain :

1. Belum diberlakukannya peraturan daerah secara tegas, khususnya adanya temuan penyimpangan peraturan daerah kaitannya dengan proses pembangunan tanpa adanya Izin Mendirikan Bangunan ( IMB)

2. Beberapa pengembang yang tidak memenuhi aturan dalam hal penyediaan sarana fasilitas umum dan fasilitas sosial yang sebenarnya merupakan kewajiban pengembang dalam pembangunan perumahan yang tertuang di dalam peraturan daerah.

3. Tempat Pembuangan Akhir (TPA) Sampah di Cipecang Tangerang Selatan daya tampungnya sudah tidak mencukupi kebutuhan Kota Tangerang Selatan

4. Penyerapan Anggaran di Pemerintahan Daerah Kota Tangerang Selatan hanya berkisar $78,59 \%$

5. Potensi pendapatan dari pajak dan retribusi daerah di Kota Tangerang Selatan belum digarap secara optimal

6. Proses pengadaan barang dan jasa masih belum sepenuhnya dapat dilaksanakan tepat waktu sesuai jadwal rencana penyelesaian pekerjaan sehingga berdampak pada mundurnya waktu pelaksanaan program. 
7. Infrastruktur jalan di Kota Tangeramg Selatan masih banyak yang rusak

8. Pelayanan publik seperti manajemen transportasi dan tata ruang, di bidang pendidikan, adiministrasi kependudukan dan kesehatan

9. Opini publik di sebagian masyarakat terkait dugaan politik dinasti kekuasaan di Banten

10. Opini publik di sebagian masyarakat terkait dugaan kasus korupsi alat kesehatan di pemerintahan Kota Tangerang Selatan

Pemaparan diatas menunjukkan bahwa permasalahan dan bidang garapan pada ranah kepemimpinan pemerintahan Kota Tangerang Selatan sangat luas. Oleh kerana keterbatasan peneliti, buku ini akan difokuskan pada dua hal, yakni menjabarkan kenapa kepemimpinan Walikota Tangerang Selatan periode Tahun 2011 - 2016 dianggap fenomenal, serta menjabarkan bagaimana Walikota Tangerang Selatan tersebut melakukan penyelenggaraan pemerintahan. 


\section{BAB II \\ KEPEMIMPINAN DAN \\ PEMERINTAHAN}

Sebelum membahas lebih jauh tentang kepemimpinan pada pemerintahan Walikota Tangerang Selatan periode 2011-2016, akan dibahas berbagai teori tentang kepemimpinan dan pemerintahan. Teori-teori tersebut akan dijadikan landasan untuk melakukan analisis kepemimpinan Walikota Tangerang Selatan. Berbagai teori yang akan dibahas pada bab ini adalah tentang teori dan gaya kepemimpinan serta kepemimpinan efektif. Selanjutnya akan dibahas pula tentang teori pemerintahan berupa konsep pemerintahan, pemerintahan daerah, otonomi daerah dan desentralisasi. Berikut adalah penjabaran atas bagian-bagian tersebut.

\section{A. Konsep Kepemimpinan}

Kepemimpinan adalah faktor kunci dalam suksesnya suatu organisasi serta manajemen. Kepemimpinan adalah entitas yang mengarahkan kerja para anggota organisasi untuk mencapai tujuan organisasi. Kepemimpinan yang baik diyakini mampu mengikat, mengharmonisasi, serta mendorong potensi sumber daya organisasi agar dapat bersaing secara baik.

Para ahli berpendapat bahwa kepemimpinan (leadership) adalah pokok atau inti dari manajemen Kepemimpinan dan berkaitan pula dengan kemampuan motivasi, komunikasi dan hubungan antar manusia. Menurut Terry dalam Sulistiyani,( 2008:12 ) Kepemimpinan adalah kegiatan untuk memengaruhi orang supaya bekerja dengan ikhlas untuk mencapai tujuan bersama

Sedangkan Rost dalam Sulistiyani, (2008:12) mengatakan bahwa Kepemimpinan adalah suatu hubungan yang saling memengaruhi diantara pemimpin dan pengikut (bawahan) yang menginginkan perubahan nyata yang mencerminkan 